\title{
A Study on Teaching Mode of freshmen's Seminars: Taking the Public Affairs Administration as an Example
}

\author{
Guihua Liu \\ School of Public Affairs and Laws \\ Southwest Jiaotong University \\ Chengdu, China \\ ktflower@126.com
}

\author{
Yuanting Wei* \\ School of Public Affairs and Laws \\ Southwest Jiaotong University \\ Chengdu, China \\ 2068921002@qq.com
}

\begin{abstract}
Seminars are the main channels for freshman to solve the problem of adapting to college life. In order to help freshman change their roles from middle-school students to college students as soon as possible, Southwest Jiaotong University set up seminars for all freshmen in 2015, and gained preliminary results. This paper takes the seminar of Public Affairs as an example, analyzing the teaching contents, forms, etc., and summarizing the teaching experiences so as to provide some references for future's seminars of Public Affairs.
\end{abstract}

Keywords-Freshmen's Seminar; Teaching Contents; Teaching Forms; Experience Reference

\section{INTRODUCTION}

Aiming at assisting the freshmen in adapting to college life better, especially to help them understand the research field and main research contents of their major in time, each university has introduced the freshmen's seminar courses one after another in recent years ${ }^{[1]}$. In 2015, Southwest Jiaotong University also launched a distributional elective called the freshmen's seminars and required each student to take a twocredit seminar course in their first year.

The maximum students of each class are 30.This new curriculum system is different from the traditional teaching in methods, contents, teaching place, the selection of teachers and so on. For freshmen who have just entered the university, what kind of knowledge should be taught and how to teach them in freshmen's seminars courses are key issues for each major. Therefore, in order to understand the needs from the perspective of receivers, the author conducted a survey that targets at the freshmen of Public affairs Administration in Southwest Jiaotong University, hoping to provide reference and basis of the teaching methods and contents for launching the new seminars in the future.

II. ANALYSIS ON THE FRESHMEN'S SEMINAR COURSES OF Public AfFairs Administration In SOUTHWESt JiaOtong UNIVERSITY

The questionnaire is mainly carried out in the freshmen of public affairs administration so as to understand their needs, improve the teaching effect of the seminar and provide suitable design for curriculum. 90 questionnaires were sent out and all of which were received back, with the recovery rate of $100 \%$. In those respondents, boys cover the percentage of $45 \%$, girls are $55 \%$, and the age of 18 to 19 years old is $85 \%$. The results of the survey are as follows:

\section{A. The teaching situation of freshmen's seminars}

The teaching time of each freshman' seminar course in Southwest Jiaotong University is 1.5 hours. Firstly, In the survey of the "is it necessary for set up seminar?" the answer of "quite necessary" and "necessary" was 92.5\%, and only $7.5 \%$ of students thought it was "unnecessary". Secondly, most of the seminars are arranged in the evening and some are arranged in the afternoon. In the survey of satisfaction with teaching time, $66.7 \%$ of the students indicated "very satisfied and relatively satisfied", and "general" was $31.9 \%$, which means that the arrangement of teaching time is relatively satisfying. In the survey of the teaching place, $68.5 \%$ of the students choose the "in a small classroom with movable desks and chairs", the proportion of choosing "outdoor lawn" was 11\%, the other 9.6\% chose "coffee shop", and only $4.1 \%$ chose "ordinary classroom". The teaching form of seminar is mainly discussing, therefore, round desk arrangement is more suitable for them.

\section{B. The teaching contents of freshmen's seminars in public affair administration}

Whether the teaching contents are reasonable or not, which is directly related to the freshmen's achievements from the seminars and the meaning of the seminars ${ }^{[2]}$. According to the survey of students' attitude towards teaching contents, the proportion of selecting "a detailed introduction to the general situation and knowledge structure of the public affairs administration specialty" is $10.8 \%$, the proportion of selecting "The discussion on the latest issues in the field of public affairs administration" is $24.3 \%$, the proportion of selecting 'the development process, current situation and the future development trend of the public affairs administration" is $37.80 \%$, and the proportion of selecting 'the research field that each teacher is good at" is $14.8 \%$. However, the percentage of choosing "the discussion on practical problems of the public affairs administration" is 12 . $2 \%$. In general, freshmen pay more attention to the development of their major. From the point of the research courses in the public affairs administration specialty of Southwest Jiaotong University, a large majority of the professors take the research field which they are good at as the main teaching contents, but most of those contents are not fit to the students' needs. 


\section{The teaching methods of freshmen's seminars in public affairs administration}

The teaching methods of freshman' seminars courses are different from the traditional ones[3]. The group discussion is most widely used in universities that offer seminars both at home and abroad[4]. In this survey, the proportion of choosing "seminar-style", "interactive discussion", and "other ways (visiting, exchanging and interacting, class displaying, going out for research, inviting senior students to share experience, holding group discussions, etc.)" is $25.7 \%$, $28.6 \%$ and $38.6 \%$ respectively. The proportion of choosing "lecturing by teacher" is only $7.1 \%$. The results suggested that the traditional instilling teaching model is not suitable for freshmen. In the course of seminars, various forms of teaching model are more attractive to freshmen.

\section{The satisfaction of the freshmen to the seminars}

To fully understand the students' satisfaction of the seminars in public affairs administration, we investigated the students' satisfaction with the teachers, contents, teaching methods and their overall satisfaction. In the survey, $74.3 \%$ of the respondents evaluate the teachers with "very satisfied" or "relatively satisfied", the proportion of choosing "unsatisfactory" is only $1.4 \%$, no one choose "very unsatisfactory" and the rest part is "General". The majority teachers of the freshman seminars in public affairs administration of Southwest Jiaotong University are professors who have accumulated rich teaching experiences and have a good understanding of this specialty so that they can meet the requirements of freshmen and realize their desire to have an opportunity to discuss with professors face to face as soon as they enter university.

In the satisfaction of teaching contents, the proportion of choosing "very satisfied" and "relatively satisfied" was $65.1 \%$, the proportion of answering "general" was $28.8 \%$, and the proportion of choosing "unsatisfactory" or "very unsatisfactory" was $6.3 \%$ in total. The satisfaction of this option is a little bit low. In view of this result, maybe we should adjust some contents of seminar in the future. In the option of teaching methods, the proportion of choosing "very satisfied" or "relatively satisfied" was $61.2 \%$ in total, the proportion of choosing "general" was 32.5\% and the proportion of choosing "unsatisfactory" or "very unsatisfactory" was $6.2 \%$. According to the investigation, at present, "lecturing by teacher" is still the primary teaching method, which lead to the satisfaction is not high. In the investigation of the overall satisfaction, the proportion of choosing "relatively satisfied" and "very satisfied" was $65.3 \%$ in all. $30.6 \%$ of the respondents viewed the option of "general" and the proportion of choosing "unsatisfactory" or "very unsatisfactory"was $4.2 \%$.

\section{E. The effects of the freshman's seminars in public affairs administration}

In the survey of effects, $55.6 \%$ of the respondents thought that the seminars had achieved the expected effects, while $44.4 \%$ of the students held a contrary opinion. Meanwhile, those students who thought that the seminars had failed to achieve the expected effects put forward some suggestions. For instance, the teacher should have sufficient preparation for seminars, strengthening the interaction with students, enriching the forms and contents and fixing the theme for each class.

\section{F. The main achievements of the students in the freshman's seminar}

In the questionnaire, we gave six options for students to sequence. Judging from all the respondents, $28.8 \%$ of the students put "changing the mode of thinking and learning methods used in middle school to the scientific thinking, innovative thinking and autonomous learning in university "as the first priority. $17.3 \%$ of the students put "a more systematic understanding of the general features of the major, and deepening the sense of identity towards it and school" ranked first. The largest proportion of the options in the second place is "enhancing the skills of communication", and the most important option in third place is "having the opportunity to interact directly with professors, experts, and eminent scholars".

\section{SUGGESTIONS ON THE FRESHMEN SEMINARS IN PUBLIC AFFAIR ADMINISTRATION}

From the investigation of the freshman's seminar courses in public affairs administration major of Southwest Jiaotong University, we can see that the freshmen hold a positive and supportive attitude towards the offering of the seminar courses, especially for the arrangement of teachers, teaching time and teaching place. More than $60 \%$ of the students are satisfied with teaching contents and forms. Freshmen have also gained a lot from seminars, including the promotion of their scientific and innovative thinking, autonomic learning ability, systematic understanding and identity of the professional profile, and their communication skills, etc. In accordance with the setting up freshmen's seminar courses in public affairs administration of Southwest Jiaotong University, the following experiences should be remembered for future's teaching.

\section{A. The design for course content}

According to the results of the investigation on the teaching contents, the overall satisfaction degree of the students is $65.1 \%$, not reaching $70 \%$ (the universal accepted satisfaction level). From the students' choice of teaching contents, the proportion of choosing "on the latest issues in the field of public affairs administration" and "on the history, present situation and developmental trend of public affairs administration" amounts to 62.1\%. Obviously, for freshmen, what they urgently need to know is the specific situation about their major, especially the learning contents, the practical significance and developmental trend of the major, the application value of the major in their future career development and so on. These were confirmed again in a later discussion with the students. The questions that often asked by sophomore and junior students are: what is the specialty of public affair administration? What role can the major play in future career development? These problems that should be solved in freshmen's seminars courses are still confusing the students who are in sophomore, junior, even in senior. As far as I am concerned, the teachers who offer freshman seminar courses mainly focus on their own research and familiar fields at present, and the introduction of the major itself is absent. Therefore, the contents of freshmen's seminars courses should be guided by the needs of the students, the professional 
contents, present situation and application in the practical work should be discussed more in future.

\section{B. The choice of teaching methods}

According to the overall satisfaction of the teaching methods, the percentage is $61.2 \%$, also failed to meet the accepted satisfaction standard of $70 \%$. From the perspective of students' choice, the proportion of "seminar" and "interactive discussion" is $54.33 \%$ in all, which is also the most popularly used teaching form for freshmen. However, up to $38.6 \%$ of the students made a choice of "visiting, exchanging and interacting, class displaying, going out for research, inviting senior students to share experience, holding group discussions, etc." To the point of the author's view, there are still a lot of teachers takes the method of "lecturing" to freshmen's seminars courses. In order to improve the teaching effects of freshman seminar, besides the study-discuss teaching pattern, we should enrich the teaching methods. Because the public affairs administration is a subject closely related to the society, it is necessary to extensively adopt the teaching methods of visiting, researching, doing social practice, etc. In the discussion with students, many sophomores and junior students hope that the curriculum can increase social investigation and practice, and they propose to present the contents of investigation and practice in the classroom.

\section{The selection and encouragement of teachers}

Excellent teachers are the key point of curriculum quality. The principal teachers of freshman seminars should have a long-term engagement in teaching and scientific research, which requires teachers with good ethics, deep academic accomplishment, rich teaching experience, and good communication skills to guarantee the high quality and standard of the courses. Because the freshmen's seminars courses are more difficult than the general curriculum and play a more important role in the students' curriculum system, excellent teachers should be selected to undertake the teaching work. In order to encourage more and more excellent teachers to participate in teaching freshman seminar, in addition to calculate the workload of the freshmen's seminars courses, universities should also take the establishment of a project for the courses into consideration. Providing a certain amount of funds and teaching resources for construction is helpful to facilitate the development of the seminar courses in public affairs administration. Besides, it can ensure the quality of the course and the enthusiasm of teachers as well.

\section{The connection between freshmen's seminar and other courses and the continuity of course effect}

The freshman seminar is just an introduction, which lays the foundation for their next three years’ professional study and even for their further development in university ${ }^{[5]}$. Therefore, it is necessary to consider the connection between those seminars courses and the following professional courses in the teaching contents, teaching forms and teacher arrangements. The lecture of major can only be done superficially, in which the focus is to guide students to establish professional thinking, above all, seminars courses can help freshmen be familiar with the university teaching methods as soon as possible. Other courses offered in major should also adopt the teaching methods of seminars, such as the interactive discussion, social investigation, social practice and individual reports etc. Aiming at cultivating students' critical and innovative thinking, academic and research abilities, encouraging students to learn with questions, and improving students' learning quality and academic level, the others professional courses should make joint efforts with freshmen's seminars, consolidate the teaching outcomes of freshmen's seminars, and gradually extend their influence so that each course can provide students with the opportunity to obtain success ${ }^{[6]}$.

\section{CONCLUSIONS}

Workable teaching methods, suitable teaching contents, excellent professors and acceptable teaching forms are key points for freshman's seminars. Fully discussion and investigation with freshmen are necessary before a freshman seminar is going to put into practice.

\section{REFERENCES}

[1] Tianying Xuan, Huang Wei. "The Experience and Analysis of undergraduate freshmen's Seminar course”. China University Teaching, vol. 2, pp:33-36, 2014.(in Chinese).

[2] Aihua Huang. "Analysis and thinking of freshmen's seminar course". China University Teaching, vol.4, pp.58-60, 2010.(in Chinese)

[3] "Exploration and Practice of freshmen's Seminar course in Researchoriented Universities” [EB/OL]. http://gjs. wh.sdu.edu.cn/show.jsp?aId=600\&class ID $=050320091218212887$, 2012-05-16.

[4] Chenxi Nie. "A study of freshmen's Seminar in the Transformation Education of Colleges and Universities: a case study of Jiangnan University”. Journal of Beijing Institute Education, vol. 3, pp.38-42, 2016.(in Chinese)

[5] Fangquan Chen, Yang Hui. "Difficulties and solutions of freshmen's seminar Construction--Based on the practice of Shanghai University". China University Teaching, vol. 3, pp.38-42. 2016.(in Chinese)

[6] Huangjie Tian, Zhimeng Liu. "Renda Model of Freshman' s seminar and The practice of research teaching.” China University Teaching, vol. 2, pp.60-63,2016.(in Chinese) 